\title{
Perubahan Budaya Tatap Muka Menjadi Online dalam Bimbingan Skripsi Mahasiswa
}

\author{
${ }^{1}$ Iswanto, ${ }^{2}$ Dasrun Hidayat \\ ${ }^{1,2}$ Universitas Adhirajasa Reswara Sanjaya (ARS University) \\ Email: ${ }^{1}$ akuiswanto@gmail.com; ${ }^{2}$ dasrun @ ars.ac.id
}

\begin{tabular}{ll}
\hline ARTICLE INFO & ABSTRACT \\
\hline & Face-to-face communication has turned directly online, which encourages changes \\
in the communication culture of lecturers. Changes in the communication culture \\
require communication competence so that face-to-face thesis guidance runs \\
effectively. Therefore, this research aims to measure the communication \\
competence of lecturers and students when carrying out online guidance. To \\
answer the research objectives, researchers used a case study with a qualitative \\
approach. The theory of analysis used in this study uses the theory of \\
communicative competence based on two dimensions: the cognitive dimension and \\
the behavioral dimension. The data technique used in this study used purposive \\
sampling, which includes several criteria for informants, including two final-year \\
students preparing a thesis using the zoom cloud meeting application, then actively \\
carrying out online thesis guidance and other supporting informants of two \\
supervisors. The results showed that the face-to-face change to online in the \\
guidance of the online thesis culture is still positive because there are \\
communication competencies that are owned; there are two components of \\
communication in online thesis guidance, namely: knowledge (knowledge) and \\
Keywords: \\
Covills (skills), the most positive communication competence-perceived by students \\
Communication \\
competence, \\
Cultural change, \\
Online guidance
\end{tabular}

\section{PENDAHULUAN}

Saat ini dunia dikejutkan dengan mewabahnya suatu penyakit yang disebabkan oleh sebuah virus yang bernama corona atau dikenal dengan sebuah istilah COVID-19. Penyebaran virus covid-19 yang begitu cepat di berbagai negara, memaksa manusia untuk melihat pandemi yang terjadi, kenyataannya dunia ini sedang mengalami perubahan. Perubahan-perubahan tersebut terjadi diberbagai bidang antara lain bidang teknologi, ekonomi, politik hingga pendidikan ditengah krisis akibat covid-19 ini. Bidang Pendidikan, akibat meluasnya penyebaran COVID-19 pemerintah terpaksa untuk menutup sekolah dan kampus. Menurut penelitian sebelumnya menyebutkan bahwa gangguan akibat covid-19 pada sektor pendidikan ini menyebabkan 45 juta siswa di Indonesia tidak bisa melanjutkan kegiatan belajar mengajar di sekolah (Azzahra, 2020).

Pemerintah Indonesia mengeluarkan kebijakan social distancing, dimana tujuan dari kebijakan tersebut diupayakan untuk meminimalisir laju persebaran virus covid-19 ditengah masyarakat. Menindak lanjuti kebijakan pemerintah mengenai social distancing, Kementerian Pendidikan dan Kebudayaan (Kemdikbud) kemudian mengeluarkan kebijakan belajar dari rumah, melalui pembelajaran secara online atau daring. Sebagai upaya untuk mendukung pembelajaran daring atau online dalam hal meningkatkan kualitas pendidikan, pengajar dan mahasiswa memanfaatkan kecanggihan teknologi dalam proses belajar mengajar.

Kecanggihan teknologi sekarang ini dinilai sebagai media yang efektif dan efisien dalam proses belajar mengajar. Media pembelajaran teknologi khususnya teknologi informasi dan komunikasi (TIK) digunakan untuk mengakses berbagai hal, mengumpulkan informasi, atau berkomunikasi satu sama lain. Teknologi yang dimaksud adalah komputer, laptop, aplikasi, dan software. TIK tersebut saat ini digunakan secara luas untuk mendukung pembelajaran jarak jauh. 
Perubahan sistem pembelajaran tentu saja berdampak pada perubahan komunikasi berbasis teknologi informasi dan komunikasi melalui media digital (Hamdani, 2020).

Meluasnya perkembangan teknologi informasi saat ini memberikan peranan yang besar dalam bidang pendidikan. Penerapan teknologi dan informasi mampu menciptakan suasana lingkungan belajar yang baru dan cara proses belajar yang baru. Dalam perkembangan teknologi dan informasi Taylor dalam (Julaeha, 2011) menyatakan bahwa dalam pelaksanaan pendidikan jarak jauh telah melampaui lima generasi yaitu, generasi pertama (the correspondence model), model kedua (the multi media model), model ketiga (the telelearning model), model keempat (the flexible elearning model), dan model kelima (intelligent flexible learning model).

Melihat hal tersebut, perubahan budaya belajar berubah dari tatap muka yang biasanya dilakukan di kelas menjadi budaya belajar online, seperti halnya yang terjadi pada mahasiswa tingkat akhir yang sedang menyusun skripsi, bimbingan yang awalnya di lakukan tatap muka kini berubah menjadi bimbingan skripsi secara daring atau online. Perubahan secara mendadak dari metode tatap muka menjadi online tersebut tentu saja membutuhkan sebuah penyesuaian. Mahasiswa dan dosen sama-sama beradaptasi terhadap cara komunikasi baru tersebut. Untuk itu, diperlukan adanya kompetensi komunikasi agar keduanya mampu mengatasi perubahan dan cepat melakukan adaptasi. Kompetensi komunikasi dapat diartikan sebagai bentuk kemampuan seseorang dalam melakukan interaksi secara baik dan efektif (Batubara, 2011).

Teori kompetensi komunikasi terdapat dua dimensi yaitu dimensi kognitif dan dimensi perilaku. Dimensi kognitif terdiri dari pemrosesan informasi secara kognitif dan proses kesadaran, sedangkan dimensi perilaku meliputi fleksibilitas perilaku, keterlibatan interaksi, gaya komunikasi dan komponen perilaku yang lainnya. Hasil penelitian sebelumnya mengenai kompetensi komunikasi pengajaran di era digital menyebutkan bahwa berdasarkan teori kompetensi komunikasi dari dimensi kognitif, didapat hasilnya yaitu pengajaran yang cocok dengan mahasiswa adalah pengajar yang mempunyai kompetensi komunikasi dalam hal mengajar di perguruan tinggi, pengajar yang harus mempunyai sikap yang ramah dan kepribadian yang bagus serta mampu memberikan pengertian dan perhatian pada mahasiswa. Kemudian dari dimensi perilaku menunjukkan berbagai manifestasi kompetensi komunikasi yaitu keterlibatan interaksi seperti pengajar yang sering berinteraksi dengan mahasiswa dan pengajar yang mampu bersikap fleksibel terhadap peraturan perkuliahan yang ada (Sirait, Novianto, \& Pamungkas, 2020). Melihat dari penelitian yang sudah dilakukan, maka peneliti akan melakukan penelitian dengan melihat dari kompetensi komunikasi antara dosen dan mahasiswa ketika melakukan proses bimbingan skripsi online, karena perubahan budaya dari tatap muka menjadi online akan positif apabila kompetensi komunikasi dimiliki.

Dalam proses bimbingan skripsi online realitasnya belum efektif seperti yang dibayangkan mahasiswa yang diharapkan mempunyai kedudukan yang sama dengan dosen lebih terkesan pasif dan belum siap dengan metode pembelajaran yang ada. Mahasiswa lebih terkesan menjadikan dosen sebagai sumber utama pengetahuan dalam bimbingan. Mahasiswa yang disiapkan untuk menjadi aktif dalam proses bimbingan tidak berperan seperti dosen yang mempunyai kedudukan yang sama seperti partisipan. Kemampuan seorang dosen yang kreatif dalam menyampaikan pesan dalam bentuk materi pada mahasiswa yang dibutuhkan. Kemampuan seseorang dalam menyampaikan isi pesan dalam dunia komunikasi biasa disebut dengan kompetensi komunikasi. Kompetensi komunikasi merupakan kemampuan seorang komunikator untuk mengirimkan pesan-pesan dengan baik menggunakan pesan yang dianggap tepat dan efektif dalam suatu situasi tertentu (Morealle et al, 2004 : 2) dalam (Wulandari, 2013).

Bimbingan skripsi pada umumnya dilakukan secara langsung, berdiskusi, dan tanya jawab. Namun, kini bimbingan skripsi beralih menjadi bimbingan online, berupa aplikasi live chat audio dan video yang disiapkan menggunakan smartphone, komputer atau perangkat lain yang terhubung dalam jaringan internet (Koutsonika 2019) dalam (Lilis Satriah, Sugandi Miharja, Wiryo Setiana, 2020).

Belajar online dalam bimbingan skripsi menggunakan aplikasi zoom cloud meeting. Aplikasi zoom cloud meeting merupakan aplikasi komunikasi dengan menggunakan video seperti menyediakan layanan konferensi jarak jauh atau pertemuan online, dan obrolan online. Aplikasi tersebut dapat digunakan dalam berbagai perangkat seluler, desktop, hingga telepon dan sistem ruang. Aplikasi zoom cloud meeting juga memungkinkan melakukan meeting sampai 100 partisipan, pengguna dapat menggunakan fitur share screen untuk berpresentasi saat meeting berlangsung, mengirim teks saat rapat sedang berlangsung, dan juga pengguna bisa menjadwalkan meeting lewat fitur schedule (jadwal). Proses bimbingan skripsi menggunakan media zoom cloud meeting ini tidak terikat jarak dan 
waktu untuk proses kegiatan bimbingannya, karena konsultasi antara dosen dan mahasiswa dapat dilakukan kapan saja sepanjang terhubung dengan internet.

Pengguna zoom cloud meeting meningkat selama pandemi COVID-19 seiring dengan belajar di rumah dan bekerja dari rumah. Bulan Desember 2019 tercatat 10 juta pengguna zoom per hari. Pada bulan Maret 2020 sampai bulan April 2020 mencatat 300 juta pengguna zoom (Indonesia, 2020). Kondisi ini memungkinkan adanya pengembangan sistem pendidikan yang lebih jauh secara global dimasa depan (Widianti, 2020).

Bimbingan skripsi secara online menggunakan aplikasi zoom cloud meeting sangat membantu karena bimbingan skripsi online ini terjadi secara realtime dan interaktif seperti tatap muka secara langsung. Bimbingan skripsi online menggunakan zoom cloud meeting menjadi salah satu bentuk layanan bimbingan yang dapat diakses setiap saat. Model bimbingan skripsi online ini dapat dijadikan sarana sebagai informasi, koordinasi, interaksi dalam jumlah banyak. Bimbingan online menjadi jawaban atas kesulitan interaksi secara tatap muka langsung (Lilis Satriah, dkk, 2020).

Bimbingan online ini membuat seseorang menjadi tidak ragu bertanya secara online. Terlihat pula pola komunikasi secara otomatis berubah menjadi pola komunikasi virtual. Dalam kondisi seperti ini, tentu saja bimbingan skripsi secara online sangat membantu dosen maupun mahasiswa. Meskipun belum berjalan ideal, sebagian mahasiswa merasakan dampak positif kebijakan belajar di rumah. Selain itu, mahasiswa tetap bisa melakukan bimbingan tatap muka meskipun lewat online.

Berdasarkan uraian di atas, peneliti tertarik meneliti tentang perubahan budaya tatap muka menjadi online dalam proses bimbingan skripsi mahasiswa. Penelitian ini bertujuan untuk mengetahui kompetensi komunikasi antara dosen dengan mahasiswa ketika melakukan bimbingan online. Adanya perubahan komunikasi dari tatap muka menjadi online tentu saja menyebabkan perubahan perilaku komunikasi. Diharapkan hasil penelitian dapat memberikan kontribusi terhadap dunia pendidikan seperti arah kebijakan yang akan ditentukan pemerintah di masa akan datang.

\section{KERANGKA TEORITIS}

\section{Kompetensi Komunikasi}

Kompetensi komunikasi adalah kemampuan individu untuk berkomunikasi secara efektif dan beradaptasi dalam segala situasi sosial, kemampuan tersebut akan mengarah pada kemampuan individu dalam bertindak dipengaruhi motivasi dan pengetahuan yang dimiliki individu. Kompetensi komunikasi merupakan suatu kemampuan yang dimiliki oleh seorang komunikator atau komunikan yang digunakan dalam proses komunikasi, menekankan pada pengetahuan dan kemampuan (Payne, 2005). Ada tiga komponen kompetensi komunikasi, digambarkan dengan skema berikut ini :

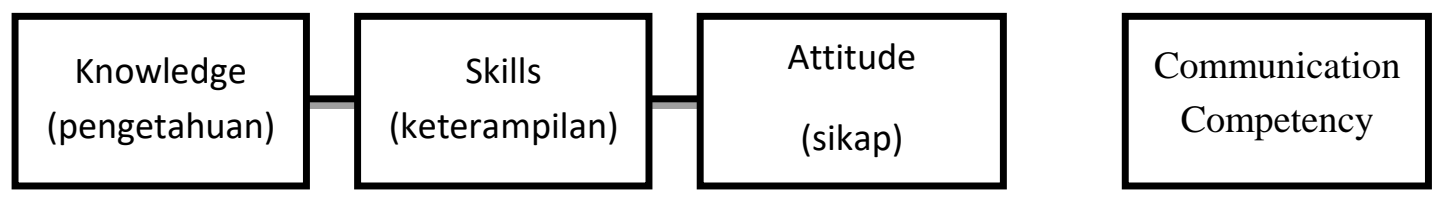

Gambar 1. Komponen Kompetensi Komunikasi Bimbingan Online

(Spitzberg \& Cupach, 1989)

Knowledge atau pengetahuan komunikasi merupakan kegiatan seorang komunikator atau komunikasi dalam mencari informasi ketika akan berkomunikasi dengan satu sama lain. Pengetahuan komunikasi ini bisa meliputi topik apa yang akan dibahas, kata-kata yang akan digunakan, pemahaman situasi dalam situasi apa pun. Pengetahuan komunikasi juga bisa merujuk pada pengetahuan bagaimana cara merencanakan, menyusun pesan dan memberikan pengetahuan yang dimiliki dalam situasi tertentu. Skills atau keterampilan komunikasi adalah kemampuan seseorang untuk dapat membimbing sehingga membentuk sebuah perilaku tertentu yang cukup dan dapat mendukung suatu proses komunikasi secara efektif.

Menurut Spitzberg dan Cupach (1989), ada ukuran dari kompetensi komunikasi yaitu pemahaman dalam berbagai proses komunikasi, perilaku komunikasi verbal dan non-verbal secara tepat, dan bertumpu pada sikap positif terhadap komunikasi. Berdasarkan dari ketiga ukuran kompetensi tersebut, maka dapat disimpulkan bahwa komunikator atau komunikan harus memiliki kemampuan komunikasi dengan syarat yaitu harus mengerti apa yang harus dilakukan dalam berbagai

Iswanto, Dasrun Hidayat (Perubahan Budaya Tatap Muka Menjadi Online dalam Bimbingan...) 
situasi apa pun, mengembangkan perilaku yang dapat menghasilkan pesan yang tepat dan menghasilkan hal yang positif, dan juga peduli terhadap tindakan yang dilakukan serta peduli pada proses komunikasi.

\section{Perilaku Komunikasi}

Perilaku merupakan suatu tindakan, tingkah laku dan interaksi antara seorang individu dengan individu lainnya. Perilaku komunikasi yaitu suatu tindakan atau perilaku komunikasi baik itu berupa verbal ataupun non verbal yang ada pada tingkah laku seseorang. Menurut Kwick dalam Notoatmodjo (2003), perilaku adalah suatu tindakan atau aktivitas individu yang dapat diamati dan bahkan dapat dipelajari (Kalangi, 2011).

Perilaku komunikasi adalah suatu tindakan dan aktivitas manusia dalam berkomunikasi, baik secara individu maupun kelompok. Dalam kehidupan sehari-hari tanpa disadari atau tidak, komunikasi merupakan bagian dari kehidupan manusia yang tidak bisa di tinggalkan. Setiap individu hidup dalam bermasyarakat sejak manusia dilahirkan sudah berkomunikasi dengan lingkungannya (Jufri, Sirajuddin, \& La Iba, 2017).

Adapun teori analisis yang di gunakan pada penelitian ini yaitu peneliti akan menggunakan teori kompetensi komunikasi yang mengintegrasikan dua dimensi (Zlatić, L., Bjekić, Marinković, \& Bojović, 2014), yaitu pertama, dimensi kognitif terdiri dari proses kesadaran diri atau self-monitoring dan pemrosesan informasi secara kognitif contohnya kesadaran interpersonal, perspektif sosial, penangkapan, konstruksi kognitif, empati, pemantauan diri, dan lain-lain. Kedua, dimensi perilaku yaitu menyangkut kemampuan individu untuk mencapai suatu tujuan komunikasi melalui penerapan yang efektif dari keterampilan perilaku. Dimensi perilaku menunjukkan berbagai manifestasi dari kompetensi komunikasi contohnya seperti keterlibatan dalam interaksi, mendengarkan, fleksibilitas perilaku, gaya komunikasi, dan komponen perilaku lainnya.

\section{METODE PENELITIAN}

Penelitian ini menggunakan pendekatan kualitatif dengan metode studi kasus. Penelitian dengan menggunakan pendekatan kualitatif yaitu mencoba menjelaskan suatu fenomena dengan mengumpulkan sumber data yang selengkap-lengkapnya. Pendekatan kualitatif digunakan untuk membangun sebuah makna tentang suatu fenomena berdasarkan dari sudut pandang dari para partisipan (Saifulloh, 2020). Struktur studi kasus yaitu memusatkan pada satu objek sebagai kasus, konteks, isu, dan permasalahan yang dapat diambil. Metode penelitian yang digunakan dalam penelitian ini yaitu studi kasus peneliti. Studi kasus dapat diartikan sebagai sebuah metode atau strategi dalam suatu penelitian untuk mengungkap kasus tertentu. Pada penelitian ini yang menjadi kasus adalah perubahan budaya tatap muka menjadi online pada bimbingan skripsi.

Paradigma yang digunakan dalam penelitian ini adalah paradigma konstruktivisme. Konstruktivisme menilai tingkah laku manusia secara fundamental, yang bertujuan untuk mengonstruksi realitas sosial baik dari pemberian makna maupun pemahaman perilaku (Umanailo, 2019). Adapun makna yang akan dikonstruksi pada penelitian ini adalah kompetensi komunikasi antara dosen dengan mahasiswa ketika sedang melakukan bimbingan online. Adanya perubahan komunikasi dari tatap muka menjadi online tentu saja menyebabkan perubahan perilaku komunikasi di antara keduanya. Proses komunikasi mempengaruhi persepsi manusia seperti perasaan, emosi dan nilai teknologi mempengaruhi komunikasi melalui teknologi yang baru (Gerry, 2019). Dalam hal ini media merespons perkembangan sosial dan perubahan budaya komunikasi pada media.

Berdasarkan uraian di atas, peneliti memfokuskan penelitian mengenai perubahan budaya tatap muka menjadi online dalam bimbingan skripsi mahasiswa. Teknik pengumpulan data primer diperoleh dengan melakukan wawancara daring (online) menggunakan media zoom cloud meeting. Hal ini dilakukan mengingat keterbatasan keadaan yang mengharuskan untuk di rumah saja. Data sekunder diambil dari studi pustaka berupa artikel yang dipublikasikan di jurnal. Pemilihan subjek penelitian, peneliti menggunakan purposive sampling dengan menyertakan beberapa kriteria meliputi, dua (2) mahasiswa tingkat akhir yang sedang menyusun skripsi dengan menggunakan aplikasi zoom cloud meeting, kemudian aktif dalam melaksanakan bimbingan skripsi online dan 2 informan pendukung lainnya terdiri 2 dosen pembimbing. 


\section{HASIL PENELITIAN DAN DISKUSI}

\section{Kompetensi Komunikasi dalam bimbingan online}

Komunikasi yang efektif mahasiswa dengan dosen sangat penting dalam bimbingan online, karena dengan komunikasi yang efektif maka akan menghasilkan output yang positif juga bagi mahasiswa. Meskipun setiap hari individu melakukan komunikasi, akan tetapi individu jarang mengetahui seberapa efektivitas komunikasi yang dilakukan, baik itu secara individual, secara profesional ataupun secara sosial.

Kompetensi komunikasi dalam bimbingan online tertuju pada kemampuan individu untuk berkomunikasi secara efektif. Komponen kompetensi ini berupa pengetahuan komunikasi, keterampilan komunikasi, dan sikap atau attitude. Ada 3 komponen kompetensi komunikasi dalam bimbingan online, yang pertama pengetahuan (knowledge), kedua keterampilan (skills), dan yang ketiga yaitu sikap (attitude).

Pada komponen pengetahuan, proses komunikasi yang dilakukan dosen saat bimbingan online menjadi perhatian. Pengetahuan komunikasi mengacu pada proses berkomunikasi dalam bimbingan online. Pengetahuan komunikasi meliputi topik apa saja yang akan disampaikan, kata-kata yang digunakan ketika bimbingan online, pemahaman terhadap proses komunikasi dalam berbagai konteks. Pengetahuan komunikasi juga merujuk pada pengetahuan bagaimana cara menyusun pesan, merencanakan dan memberikan pengetahuan yang dimiliki. Saat mewawancarai beberapa informan perihal apa saja yang harus dipersiapkan dalam saat berkomunikasi dengan dosen pembimbing ketika bimbingan, salah satu informan menjawab :

"Pertama yang saya persiapkan jika ingin melakukan bimbingan adalah saya harus berada di kosan karna ada WIFI, Biasanya saya menyelesaikan terlebih dahulu tugas yang sebelumnya sudah diberikan pada saya seperti membuat skema penelitian atau yang lain, kalau dari penampilan saya mempersiapkan diri seperti menggunakan pakaian yang rapi agar terlihat sopan" (Dina Fauziyyah, wawancara, 2020)

Adapun informan lain menjawab :

"Yang biasa saya persiapkan sebelum bimbingan adalah yang pasti bahan seputar skripsi, jika menjelaskan biasanya mempersiapkan/menyusun kalimat atau kata-kata yang akan saya sampaikan terlebih dahulu agar memudahkan saya untuk menyampaikan pesan tersebut"(Veny Purba, wawancara, 2020).

Begitu pun dengan dosen, ketika akan melakukan bimbingan online, dosen akan mempersiapkan materi yang akan disampaikan kepada mahasiswa bimbingan, menyiapkan draf skripsi, pemahaman terhadap penelitian, dan memahami teori yang terkait. Dalam hal menyampaikan pesan seorang dosen harus berkomunikasi dengan jelas contohnya memberikan analogi atau contoh agar mahasiswa bimbingannya dapat memahami apa yang disampaikan ketika bimbingan online. Dan hal ini, dosen berperan penting dalam hal pengetahuan komunikasi karena dosen mempunyai pengetahuan apa yang harus disampaikan pada mahasiswa, dan dalam bagaimana cara dosen dapat mendorong mahasiswanya aktif berpartisipasi dalam kegiatan bimbingan online menggunakan aplikasi zoom cloud meeting.

Berdasarkan hasil wawancara yang telah dilakukan maka dapat disimpulkan bahwa pengetahuan komunikasi dalam proses komunikasi bimbingan online sangat penting dilakukan. Dengan memiliki pengetahuan maka proses komunikasi akan berjalan dengan baik sehingga proses bimbingan online akan berjalan lancar dan efektif.

Komponen komunikasi yang kedua yaitu skill atau keterampilan. Keterampilan komunikasi adalah kemampuan seseorang untuk dapat membimbing sehingga menghadirkan sebuah perilaku tertentu dan dapat mendukung suatu proses komunikasi secara tepat dan efektif. Keterampilan komunikasi yang baik akan meningkatkan semangat dalam belajar mahasiswa dan membantu mahasiswa dalam mendapatkan informasi dan keterangan yang dibutuhkan mahasiswa. Keterampilan komunikasi dosen dan mahasiswa juga akan memberikan suasana yang mendukung dalam pembelajaran bimbingan online menggunakan aplikasi zoom cloud meeting ini. Pada aplikasi zoom cloud meeting terdapat fitur share screen yang memudahkan dosen dan mahasiswa untuk bisa

Iswanto, Dasrun Hidayat (Perubahan Budaya Tatap Muka Menjadi Online dalam Bimbingan...) 
berpersentase dan menampilkan materi di layar pc pada saat melakukan video conference saat bimbingan online. Dengan adanya keterampilan komunikasi yang dimiliki, mahasiswa dapat memiliki kepercayaan diri dalam mengemukakan pendapat, dan membangun sikap yang positif ketika melakukan bimbingan online.

Keterampilan komunikasi dalam penelitian ini juga dapat dilihat dari bagaimana cara individu menerima pesan dan mengolah pesan saat bimbingan skripsi online. Dari data yang didapatkan, cara mahasiswa menerima dan mengolah pesan pada saat bimbingan skripsi online yaitu dengan cara memperhatikan dengan cara yang cermat, mencatat apa yang disampaikan oleh dosen atau direkam supaya bisa mengulang untuk didengarkan dan kemudian dipahami pelan-pelan. Kemudian cara dosen dalam menerima dan mengolah pesan pada saat bimbingan skripsi online yaitu ketika ada pertanyaan dari mahasiswa pertama-tama pahami dulu pertanyaannya seperti apa tujuannya, kemudian setelah dipahami baru memberikan pemahaman terhadap pertanyaan tersebut, memberikan contoh atau analogi agar mahasiswa dapat mudah memahami, dan menanyakan balik kepada mahasiswa untuk mengetahui apakah mahasiswa paham dengan apa yang di sampaikan.

Komponen komunikasi yang ketiga yaitu sikap atau attitude. Sikap atau etika adalah suatu tindakan yang berdasarkan pada kepercayaan, nilai dan prinsip moral yang dimiliki individu. Contohnya ketika bertemu dengan orang yang lebih tua, hendaknya terlebih dahulu menyapa dan mengucapkan salam, serta berbicara sopan. Pada proses bimbingan skripsi online terlihat ketika akan melakukan video conference melalui zoom cloud meeting, mahasiswa harus terlihat berpakaian rapi dan sopan, tidak banyak melakukan gerakan saat bimbingan skripsi online, mendengarkan ketika dosen berbicara dan teman lain yang sedang berpendapat.

Berdasarkan hasil observasi dan wawancara, peneliti dapat menyimpulkan bahwa kompetensi komunikasi sangat penting dimiliki dalam semua jenis komunikasi, baik komunikasi interpersonal secara langsung maupun tidak langsung. Komunikasi interpersonal tidak langsung yaitu komunikasi yang dilakukan melalui media daring, seperti komunikasi yang terjadi pada bimbingan online menggunakan aplikasi zoom cloud meeting. Terdapat perbandingan antara komunikasi tatap muka langsung dengan tatap muka tidak langsung atau menggunakan media daring yaitu menurut salah satu informan, meskipun komunikasi daring ini kurang efektif dilakukan namun menurutnya komunikasi daring ini cukup menarik karena beberapa faktor yakni komunikasi daring dapat meningkatkan keterbukaan diri dan pengendalian diri dari presentasi diri, individu akan merasa lebih aman dan lebih bebas dalam berinteraksi interpersonal dibandingkan dengan berinteraksi tatap muka langsung. Hal ini sangat penting apalagi bagi seseorang yang memiliki hambatan sosial dan sering merasa malu ketika berkomunikasi secara langsung.

\section{Perilaku Komunikasi dalam bimbingan online}

Perilaku komunikasi adalah suatu tindakan atau respons seseorang dalam berkomunikasi dalam situasi apa pun. Perilaku komunikasi dapat diamati melalui kebiasaan komunikasi seseorang, sehingga perilaku komunikasi seseorang bisa disebut pula dengan kebiasaan seseorang. Pengertian dari perilaku komunikasi tidak akan lepas dari pengertian perilaku dan komunikasi. Perilaku tersebut pada dasarnya berorientasi pada tujuan. Perilaku atau kebiasaan seseorang pada umumnya dipengaruhi oleh motivasi dan keinginan seseorang untuk mendapatkan sesuatu dan mencapai tujuan tertentu. Hasil dari perilaku komunikasi tersebut yang mengharuskan seseorang untuk mendapatkan titik temu dari tindakannya. Perilaku komunikasi akan menampilkan suatu teknik dan juga keterampilan dari seorang individu untuk mencapai tujuan komunikasi. Hal tersebut dapat diterapkan pada seseorang yang mengatur teknik komunikasinya baik itu secara verbal maupun secara non verbal. Perilaku komunikasi ini dibagi menjadi dua yaitu perilaku komunikasi verbal dan perilaku komunikasi non verbal. Salah satu contoh dari perilaku komunikasi verbal dan non verbal dapat dilihat dari berbagai sudut pandang, baik komunikasi secara langsung maupun tidak langsung. Perilaku komunikasi yang dilakukan pada saat bimbingan online, salah satu informan menjawab:

“..saya sebenarnya kurang yakin dengan perilaku verbal saya, tapi jika diingat biasanya saya akan menggunakan bahasa yang semi formal tapi mudah dimengerti ketika bimbingan. Saya biasanya tidak banyak bicara jika saya rasa bahan bimbingan saya sudah tersampaikan seluruhnya, kalau untuk perilaku komunikasi non verbalnya terkadang ada gerakan tangan yang secara tidak sadar saya gunakan pada saat saya berbicara atau menjelaskan sesuatu selain. Terkadang saya melihat teman- 
teman saya kebingungan dengan ekspresi wajah yang darat Ketika dosen pembimbing saya menjelaskan "(Dina Fauziyyah, wawancara, 2020)

Berdasarkan jawaban dari informan diatas, diperoleh hasil bahwa perilaku komunikasi verbal yang terjadi saat bimbingan skripsi online dapat dilihat dari penggunaan bahasa yang digunakan mahasiswa maupun dosen ketika bimbingan, penggunaan vocabulary yang luas. Sedangkan perilaku komunikasi non verbal saat bimbingan skripsi online, berupa ekspresi wajah dan gerakan tubuh seperti gerakan tangan dan lain-lain. Perilaku komunikasi dapat dilihat dari kompetensi komunikasi yang dimiliki pada saat bimbingan online.

Kompetensi komunikasi jika dikaitkan dengan teori analisis kompetensi komunikasi dimensi kognitif dan dimensi perilaku, maka hasil analisisnya berdasarkan wawancara kepada informan adalah kompetensi komunikasi pada bimbingan online ini harus dibangun dan di tingkatkan dengan cara yaitu pengajar atau dosen harus memiliki kemampuan yang kompeten, sikap dan kepribadian harus ramah dan juga mampu memberikan pengertian pada mahasiswa bimbingannya. Peneliti juga mendapatkan hasil bahwa hubungan baik dosen dengan mahasiswa dapat mempengaruhi pemahaman mahasiswa pada materi yang disampaikan, karena jika seorang dosen dekat dengan mahasiswanya. Hal tersebut akan membuat mahasiswa untuk tidak takut untuk bertanya dan membuat proses belajar menjadi lebih dinikmati oleh mahasiswa dan menjadi lebih efektif. Begitu juga dalam rasa empati, empati antara dosen dan mahasiswa pada saat bimbingan akan mempermudah dalam proses pemahaman materi, pentingnya rasa empati dosen pada saat mahasiswanya tidak cepat tanggap dalam memahami materi ketika bimbingan online.

Dimensi kedua kompetensi komunikasi yaitu dimensi perilaku. Dimensi perilaku menunjukkan berbagai jenis manifestasi kompetensi komunikasi, antara lain meliputi keterlibatan dalam interaksi, sikap fleksibel, mendengarkan, gaya atau pola komunikasi yang dilakukan dan komponen perilaku komunikasi lainnya. Berdasarkan hasil wawancara, diperoleh hasil bahwa pentingnya keterlibatan interaksi seorang pengajar atau dosen yaitu supaya mahasiswa bisa menjadi lebih mengerti tentang materi yang disampaikan pada saat bimbingan online.

Berdasarkan hasil observasi dan hasil wawancara kepada beberapa informan juga didapatkan bahwa bimbingan skripsi secara daring atau online, terdapat beberapa kendala yang terjadi yaitu yang pertama adalah terkait masalah koneksi internet, sehingga menyebabkan gangguan yang mengakibatkan mahasiswa kurang paham apa yang disampaikan dosen begitu pun dosen tidak paham apa yang dibicarakan mahasiswanya, tanggapan dari mahasiswa atau dosen pun menjadi lambat. Yang kedua masalah waktu, durasi pada aplikasi zoom cloud meeting dalam melakukan video conference terbatas hanya 40 menit sehingga ketika bimbingan skripsi sedang berlangsung tiba-tiba terputus dan juga harus login menggunakan link yang baru. Dan yang ketiga adalah masalah teknis, masih ada beberapa dosen pembimbing yang mengalami suatu kendala teknis saat menggunakan aplikasi untuk bimbingan skripsi online sehingga perlu adanya sebuah persiapan sebelum melakukan video conference mengingat tidak semua dosen paham dan bisa langsung terbiasa dengan teknologi dan perubahan budaya komunikasi secara online.

\section{SIMPULAN}

Berdasarkan hasil penelitian dan dari data-data yang penulis dapatkan, diperoleh kesimpulan bahwa komponen komunikasi yang ada pada bimbingan skripsi online yaitu terdiri dari 3 komponen antara lain yaitu pengetahuan atau knownledge, keterampilan (Skill), dan sikap (Attitude). Pada komponen pengetahuan meliputi persiapan yang dilakukan dalam saat akan melakukan bimbingan online seperti topik apa saja yang akan disampaikan, kata-kata yang digunakan ketika bimbingan online, serta pemahaman terhadap proses komunikasi dalam berbagai konteks. Keterampilan atau skills, mahasiswa menerima dan mengolah pesan pada saat bimbingan skripsi online yaitu dengan cara memperhatikan dengan cara yang cermat, mencatat apa yang disampaikan oleh dosen atau direkam supaya bisa mengulang untuk didengarkan dan kemudian memahami apa yang di katakan oleh dosen. Sikap atau attitude pada proses bimbingan skripsi online, sikap dapat dilihat dari ketika akan melakukan video conference melalui zoom cloud meeting, mahasiswa harus terlihat berpakaian rapi dan sopan, tidak banyak melakukan gerakan saat bimbingan skripsi online, mendengarkan ketika dosen berbicara dan teman lain yang sedang berpendapat.

Berdasarkan teori kompetensi komunikasi dari dimensi kognitif adalah jawaban informan yang mendominasi antara lain informan tersebut berpendapat bahwa kompetensi komunikasi pada

Iswanto, Dasrun Hidayat (Perubahan Budaya Tatap Muka Menjadi Online dalam Bimbingan...) 
bimbingan online ini harus dibangun dan ditingkatkan dengan cara yaitu pengajar atau dosen harus memiliki kemampuan yang kompeten, sikap dan kepribadiannya harus ramah dan juga mampu memberikan pengertian pada mahasiswa bimbingannya. Sedangkan pada dimensi perilaku yaitu pentingnya keterlibatan interaksi seorang pengajar atau dosen yaitu supaya mahasiswa bisa menjadi lebih mengerti tentang materi yang disampaikan pada saat bimbingan online.

\section{DAFTAR PUSTAKA}

[1] AAzzahra, N. F. (2020). Mengkaji Hambatan Pembelajaran Jarak Jauh di Indonesia di Masa Pandemi Covid-19. Cips, 19(2), 1-9.

[2] Batubara, A. K. (2011). URGENSI KOMPETENSI KOMUNIKASI PUSTAKAWAN DALAM MEMBERIKAN LAYANAN KEPADA PEMUSTAKA. Jurnal Iqra, 5(01), 50-58.

[3] Febiyana, A., \& Turistiati, A. T. (2019). KOMUNIKASI ANTARBUDAYA DALAM MASYARAKAT MULTIKULTUR (Studi Kasus pada Karyawan Warga Negara Jepang dan Indonesia di PT. Tokyu Land Indonesia). LUGAS Jurnal Komunikasi, 3(1), 33-44. https://doi.org/10.31334/ljk.v3i1.414

[4] Gerry. (2019). Medium Theory (Teori Media). Retrieved from http://gerry05.blogspot.com/2019/04/medium-theory-teori-media.html

[5] Hamdani S.Pd, Mp. (2020). Pengaruh Komunikasi Sosial di Tengah Wabah Covid-19. Retrieved from https://santerdaily.com/lainnya/profil/pengaruh-komunikasi-sosial-di-tengahwabah-covid-19/

[6] Indonesia, B. (2020). Virus corona: Pengusaha Zoom, Eric Yuan yang menjadi miliarder karena Covid-19. Retrieved from https://www.bbc.com/indonesia/dunia-52461912

[7] Jufri, M., Sirajuddin, \& La Iba. (2017). PERILAKU KOMUNIKASI PENGGUNA JEJARING SOCIAL PATH (Studi Pada Mahasiswa Fakultas Ekonomi Dan Bisnis Universitas Halu Oleo Kendari).

[8] Julaeha, S. (2011). Virtual Learning: Pemanfaatan Teknologi Informasi Dan Komunikasi Untuk Meningkatkan Kualitas Pembelajaran. Majalah Ilmiah Pembelajaran, 7(2).

[9] Kalangi, J. S. (2011). PERILAKU KOMUNIKASI MAHASISWA PENGGUNA SOSIAL MEDIA PATH. Acta Diurna, 5(3).

[10] Lilis Satriah, Sugandi Miharja, Wiryo Setiana, A. S. R. (2020). Optimalisasi bimbingan online dalam upaya mencegah penyerbaran virus Covid-19. Journal of Food System Research, 2(2), 54-65. https://doi.org/10.5874/jfsr.2.2_54

[11] Payne, H. . (2005). Journal of Leadership \& Organizational School. 11(2).

[12] Saifulloh, M. (2020). Subordinat Perempuan Dalam Aplikasi Percakapan Grup Whatsapp ( Studi Kasus Penggunaan Sticker Sensual Di Grup Whatsapp ). 4(1), 43-48.

[13] Sirait, N. A., Novianto, I., \& Pamungkas, A. (2020). Kompetensi Komunikasi Pengajar Perguruan Tinggi Di Era Digital. Jurnal Uniga, 6, 426-434.

[14] Umanailo, M. C. B. (2019). Paradigma Konstruktivis. 96-97. https://doi.org/10.31219/osf.io/9ja2t

[15] Widianti, Y. (2020). Wabah Corona Bikin Unduhan Aplikasi Zoom Naik 1.270 Persen. Retrieved from https://tekno.tempo.co/read/1324176/wabah-corona-bikin-unduhan-aplikasizoom-naik-1-270-persen/full\&view=ok

[16] Wulandari, N. (2013). Kompetensi Komunikasi Guru dalam Kegiatan Belajar Mengajar Berbasis Student Center Learning di SMA N 9 Semarang Skripsi Disusun untuk memenuhi persyaratan menyelesaikan Pendidikan Strata 1 Penyusun Nama: Novita Wulandari.

[17] Zlatić, L., Bjekić, D., Marinković, S., \& Bojović, M. (2014). Development of Teacher Communication Competence. Procedia - Social and Behavioral Sciences. 